\title{
Stable isotope and fatty acid evidence for uptake of organic waste by green-lipped mussels Perna viridis in a polyculture fish farm system
}

\author{
Qin-Feng Gao ${ }^{1}$, Paul K. S. Shin ${ }^{1,2}$, Guang-Hui Lin ${ }^{3,4}$, Shi-Ping Chen ${ }^{3}$, \\ Siu Gin Cheung ${ }^{1, *}$ \\ ${ }^{1}$ Department of Biology and Chemistry, and ${ }^{2}$ Centre for Coastal Pollution and Conservation, City University of Hong Kong,
Tat Chee Avenue, Kowloon, Hong Kong SAR, China
${ }^{3}$ Laboratory of Quantitative Vegetation Ecology, Institute of Botany, the Chinese Academy of Sciences,
Beijing 100093, China
${ }^{4}$ Department of Global Ecology, Carnegie Institution of Washington, 260 Panama Street, Stanford, California 94305, USA
}

\begin{abstract}
To evaluate the feasibility and capability of using filter-feeding bivalves as biofilters for organic waste derived from fish faeces and feed wastage in marine fish culture activities, a polyculture system comprising fish and green-lipped mussels Perna viridis was developed by transplantation of mussels into fish cages. As a control, mussels from the same population were simultaneously transplanted to a distant reference site free of effects from fish farming activities. After 3 mo acclimation, samples of mussel tissue, particulate organic matter (POM), fish feed and fish faeces were collected for measurements of carbon and nitrogen isotopic ratios and fatty acid profiles. Enrichment of ${ }^{13} \mathrm{C}$ and ${ }^{15} \mathrm{~N}$ in mussel tissue collected inside the fish cages as compared to those at the reference site indicated the uptake and assimilation of isotopically heavier fish feed and fish faeces. Compared with mussels from the reference site, the pattern of fatty acid profiles and single fatty acids of mussels in fish cages also tended to be closer to fatty acid profiles of fish feed from fish farms. Based on the concentration-weighted isotope mixing model, the proportions of mussel biomass assimilated from POM, fish feed and fish faeces to mussel dietary consumption were 68.3, 27.5 and $4.2 \%$, respectively. The direct uptake of organic waste from fish farms by filter-feeding mussels is different to their consumption of phytoplanktonic biomass, because the nutrient flux is shifted between these 2 distinct pathways.
\end{abstract}

KEY WORDS: Fish farming $\cdot$ Stable isotopes $\cdot$ Fatty acid profiles $\cdot$ Perna viridis $\cdot$ Biofiltration

\section{INTRODUCTION}

Studies have demonstrated that fish farming activities in coastal waters can result in marine pollution, owing to the release of organic and inorganic waste from uneaten feed, faeces and dissolved excretory products (Wu et al. 1994, Karakassis et al. 2000). In Europe, North America and South America, intensive salmonid fish culture using artificial feed is common. However, non-salmonid species (such as groupers, sea breams and seabass) are traditionally reared in Asian-
Pacific waters and fed trash fish (mainly anchovies Thryssa spp.). While modern fish feed becomes more closely aligned with the dietary requirements of fish culture and produces less feed wastage, trash fish feed is inherently wasteful and causes organic pollution because of its high protein content and tendency to break up and shed small unconsumed particles during feeding (Leung et al. 1999). Gowen \& Bradbury (1987) showed that $40 \%$ of feed provided to fish could become organic waste in the form of uneaten pellets and faeces. 
Filter-feeding bivalves take up particulate matter with considerable efficiency owing to the nature of their high filtration rate and high population density (for reviews see Dame 1993, 1996). Potential utilization of the large amount of nutrients in excess suspended trash fish feed by filter-feeding bivalves has not been documented; however, Yokoyama et al. (2002) reported that mussels could efficiently take up the uneaten fish meal and flour in shrimp ponds. Thus, in an integrated polyculture system combining fish and filter-feeding mussels, mussels can function as a selfregulator for cycling of particulate matter (Folke \& Kautsky 1989). Based on the pumping rate, Taylor et al. (1992) estimated that 3 min were sufficient for 1.2 million mussels attached on salmon culture nets to filter the entire volume of water in the fish pen $(5 \times 5$ $\times 6 \mathrm{~m}$ ). Through filter feeding, mussels may utilize organic waste from the fish culture cages as food sources and reduce pollution (Folke \& Kautsky 1989, Shpigel et al. 1997).

Studies of fish culture effluents on the physiological status of bivalves in an integrated polyculture system have drawn much attention, as they may offer a means of enhancing commercial bivalve production and financial benefits. For example, cultured mussels might be used to recycle excess algal biomass that results from fish farming and hence improve production (Larsson 1985, Jones \& Iwama 1991). Stirling \& Okumus (1995) compared growth and production of the blue mussel Mytilus edulis suspended at salmon cages with those at shellfish farms, and found significantly increased growth and production of mussels in the salmon farms. Multiple regression models indirectly revealed that the increment of mussel growth was due to elevated particulate organic matter (POM) at fish farms. All these studies concerning the effects of fish farming on bivalve performance were focused on indirect factors, i.e. changes in primary production due to fish farming and subsequent effects on cultured bivalves. Information regarding the direct contribution of farming waste as food sources (i.e. feed residues and faecal pellets) to bivalves within polyculture systems was limited (Mazzola \& Sará 2001, Yokoyama et al. 2002).

Utilization of various food sources by bivalves has traditionally been evaluated by means of direct gut content analysis (Kamermans 1994, Lehane \& Davenport 2002). However, trophic models based on dietary observations can only represent an instant snapshot of food ingested by the bivalves. The application of stable isotopes may overcome such limitations. Carbon and nitrogen stable isotopes change in a predictable way when transferred along trophic pathways (Peterson \& Fry 1987). Moreover, the stable isotope approach offers distinct advantages over conventional dietary tech- niques because (1) evaluation of food sources is based on assimilated instead of ingested food, and (2) assimilated matter represents time-integrated utilization of food (Hobson \& Welch 1992). This method may be particularly useful in revealing the food sources of bivalves because the recognition of gut content is difficult, sometimes even impossible, due to the small size of food particles. There has been increasing application of stable isotopes as tracers to follow the flux of organic matter or pollutants along food chains or food webs in both terrestrial and aquatic environments (e.g. Fry 1988, Yamamuro 1999, Bearhop et al. 2000, Collier et al. 2002, Vizzini et al. 2002).

Fatty acid profiling is another potential trophic marker technique for tracing food sources. The feasibility of using fatty acids as trophic markers to trace predator-prey relationships is based on the observation that marine primary producers develop certain fatty acid patterns that may be transferred conservatively to, and hence can be recognized in, primary consumers (Dalsgaard et al. 2003). The simultaneous use of stable isotopes and fatty acids as trophic markers may mutually confirm the information obtained from single marker technique alone. Multiple marker techniques may also complement each other by the elimination of 'blind spots' that may arise from using certain single marker techniques alone. In particular, overlap of single markers between diverse target food compartments frequently occurs under natural conditions (Nichols et al. 1985, Canuel et al. 1995, Kharlamenko et al. 2001). However, microalgae, bacteria and animals contain different unique fatty acids despite the possible overlap of stable isotope signatures. The presence of these specific fatty acids in consumer tissues may thus indicate the source of food items.

Green-lipped mussels Perna viridis are widely distributed in the Indo-Pacific region (Siddall 1980) and are 1 of the 5 mussel species cultured commercially in Guangdong and other southern provinces in China (Guo et al. 1999). In Hong Kong, P. viridis is distributed widely from oceanic to estuarine waters and is a dominant subtidal species with highest densities recorded from Victoria Harbour (246 ind. $\mathrm{m}^{-2}$ ) and Tolo Harbour (>1000 ind. $\mathrm{m}^{-2}$ ) (Huang et al. 1985). Although this species is not intentionally cultured in Hong Kong, its abundance on fish cages is so great that it is collected by fish farmers as a by-product. Its high growth rate (8 to $10 \mathrm{~mm} \mathrm{mo}^{-1}$ ) and natural abundance demonstrate the potential of $P$. viridis as an aquaculture species (Cheung 1991). The objectives of our present study were to identify the potential food sources of $P$. viridis reared in a polyculture system with fish, and to quantify the contribution of respective food sources to assimilation in mussels using dual carbon and nitrogen stable isotopes and fatty acid profiles as tracers. Based 
on this quantification, the feasibility and capability of mussels as biofilters to reduce pollution from fish farming were evaluated.

\section{MATERIALS AND METHODS}

Study area and sampling scheme. The study area was a marine fish culture zone located in Kau Sai Bay, which is a semi-closed embayment in the eastern waters of Hong Kong $\left(22^{\circ} 21^{\prime} \mathrm{N}, 114^{\circ} 19^{\prime} \mathrm{E}\right)$. There are no riverine inputs into the bay. The fish raft area, which is confined within the inner part of the bay, is approximately 4.6 ha with water depth ranging from 11 to $16 \mathrm{~m}$. Each fish cage is approximately $4 \times 4 \times 4 \mathrm{~m}$. The total fish stock is $\sim 500 \mathrm{t}$ with an average density of $4.5 \mathrm{~kg} \mathrm{~m}^{-3}$. Cultured species are mainly grouper Epinephelus awoara, snapper Lutjanus russellii and seabream Acanthopagrus latus. Small trash fish (mainly anchovies Thryssa spp.) are used as fish feed. Daily feed supply is 3 to $5 \%$ of the total stock, i.e. 15 to $25 \mathrm{t} \mathrm{d}^{-1}$.

An experimental site and a reference site were selected within the bay for mussel transplantation. The experimental site ( $12 \mathrm{~m}$ depth) was located within the fish raft area, whereas the reference site ( 14 m depth) was positioned at the mouth of the embayment, $1 \mathrm{~km}$ away from the experimental site. Our previous baseline investigation showed that the reference site was not affected by the fish farming activities in terms of water and sediment characteristics (Gao et al. 2005). Green-lipped mussels Perna viridis collected from Cheung Chau in southern waters of Hong Kong in September 2003 were attached to $3 \mathrm{~m}$ polyethylene ropes with a density of $100 \mathrm{ind} . \mathrm{m}^{-1}$ and cultured in the laboratory for $2 \mathrm{wk}$ so that the mussels could produce enough byssus to adhere tightly on the ropes. Thirty pieces of mussel ropes were simultaneously transplanted to both the experimental and reference sites.

After 3 mo in the field, triplicate mussel samples that each contained 10 individuals of 50 to $60 \mathrm{~mm}$ shell length were randomly collected from the experimental and reference sites (in December 2003). The 3 mo period was assumed to be long enough for the mussels to acclimatize to the environment and completely turn over their body reserve (Freites et al. 2002, Wong \& Cheung 2003). The epibionts on the collected mussel shell surface were removed and the mussels were cultured in filtered seawater (Whatman, GF/C) for more than $24 \mathrm{~h}$ until no more faeces were produced, so as to evacuate the gut content. The shells were removed and tissue was rinsed with distilled water to remove salts. The tissue was dried at $40^{\circ} \mathrm{C}$ for more than $72 \mathrm{~h}$ to constant dry weight. For each sample, 10 mussels were pooled, homogenized and sieved through a
$0.5 \mathrm{~mm}$ mesh size sieve. The tissue powder was tightly sealed in glass sample bottles and stored in an ultralow temperature freezer $\left(-80^{\circ} \mathrm{C}\right)$ for future analyses.

POM was sampled in water after supply of feed to the cultured fish at the experimental site was ceased for $3 \mathrm{~d}$, so that the uneaten feed fragments could completely settle on the sea bottom. The presence of any uneaten feed in water samples was first checked by microscopic analysis. Major constituents in the particulate matter included phytoplankton and detrital particles. POM samples were obtained by means of filtration and treatment with $\mathrm{HCl}$. About $30 \mathrm{l}$ seawater were collected $1 \mathrm{~m}$ beneath the surface adjacent to the mussel ropes from the experimental and reference sites with acid-treated and pre-rinsed Nalgen sample bottles. The water samples were sieved with a $200 \mu \mathrm{m}$ stainless screen prior to filtration to remove large particles, and filtered with pre-combusted $\left(450^{\circ} \mathrm{C}\right.$ for $6 \mathrm{~h}) 0.45 \mu \mathrm{m}$ Whatman GF/C glass fiber filters under vacuum suction of less than one-third atmospheric pressure. The residue on filter papers was rinsed with distilled double deionized water to remove salt adsorbed on the particle surface. To avoid chemical contamination to the collected particulate matter, distilled double deionized water was used instead of isotonic salt solution, and the short flushing time $(<1 \mathrm{~min})$ with distilled water ensured that no obvious cell rupture would occur (Currin et al. 1995, Wong \& Cheung 1999). For fatty acid analysis, filtered samples were dried and stored following the same method used for processing mussel tissue. For stable isotope measurements, the particulate matter was treated with $1.2 \mathrm{~N}$ isotonic $\mathrm{HCl}$ to remove carbonates until no more $\mathrm{CO}_{2}$ bubbles produced prior to drying and storage (Yokoyama et al. 2002).

Ten trash fish (anchovies Thryssa spp., ca. $100 \mathrm{~g}$ ) used as fish feed were taken from the fish raft. According to direct observations, only muscle of trash fish could be crushed to small particles by the cultured carnivorous fish and thus be suitable for uptake by greenlipped mussels. Hence, fillets removed from 3 to 4 trash fish were used as 1 replicate for analysis. The fish muscle was treated and stored in a similar manner to the mussel tissue for future analyses. To collect fish faeces, 5 ind. of the yellow grouper Epinephelus awoara in the culture stock were taken from fish cages where mussels were cultured. The fish were separately maintained in fiber glass tanks with circulated seawater in situ for $24 \mathrm{~h}$ and the egested faeces were collected with a pipette. Depending on the production amount, faeces collected from 1 or 2 groupers were treated as 1 replicate for analysis. After collection, the fish faeces were dried and homogenized following a method similar to that used for preparation of mussel tissue. The powdered samples were divided into 2 
parts for separate fatty acid and stable isotope analyses. The aliquot for stable isotope analysis was acidtreated prior to measurement of isotopic ratios. In the present study, 3 replicates of trash fish feed and fish faeces were collected and analyzed.

Measurements of environmental conditions. Three replicates of $1 \mathrm{l}$ water samples were collected from $1 \mathrm{~m}$ below the water surface at the experimental site in the fish culture zone and at the reference site. Magnesium carbonate ( $1 \mathrm{ml}, 1 \%)$ was added to each replicate and filtered through Whatman GF/C glass fiber filter paper. The remains retained on the filter paper were extracted with $90 \%$ acetone under refrigeration for $20 \mathrm{~h}$ and centrifuged. The extinction of the resultant solution was measured with a spectrophotometer at wavelengths of 665, 645 and $630 \mathrm{~nm}$, and the chl a concentration was calculated with the Richards formula (Strickland \& Parsons 1972). At both the experimental and reference sites, current speed and direction in the surface layer (top 2 to $3 \mathrm{~m}$ of the water column), where fish cages and mussel ropes were deployed, were continuously monitored for 2 tidal cycles once a month with a current meter (SonTek Argonaut).

Measurement of stable isotope and elemental concentrations. After pretreatment, carbon and nitrogen isotope ratios were determined using an elemental analyzer coupled with an isotope ratio mass spectrometer (EA-IRMS, ThermoFinnigan MAT Delta-plus). Results of isotope ratios were expressed in standard $\delta$-unit notation, which is defined as follows:

$$
\delta X=\left[\left(R_{\text {sample }} / R_{\text {standard }}\right)-1\right] 1000 \%
$$

where $X={ }^{13} \mathrm{C}$ or ${ }^{15} \mathrm{~N}$, and $R$ is either ${ }^{13} \mathrm{C}:{ }^{12} \mathrm{C}$ ratio for carbon or ${ }^{15} \mathrm{~N}:{ }^{14} \mathrm{~N}$ ratio for nitrogen. The values were reported relative to the Vienna Pee Dee Belemnite standard (PDB) for carbon and to air $\mathrm{N}_{2}$ for nitrogen. A laboratory working standard (glycine) was run for every 10 samples. Analytical precision was $\pm 0.1 \%$ for both carbon and nitrogen. Carbon and nitrogen concentrations of all samples were determined using a CHNS/O Analyzer (PE2400 Series II, PerkinElmer).

Fatty acid extraction and determination. Lipid of pre-weighed samples was extracted by a 2:1 chloroform-methanol solvent mixture (v/v) overnight following a slightly modified method of Bligh \& Dyer (1959). The crude extract was then washed with $0.04 \% \mathrm{CaCl}_{2}$ solution ( 0.2 of the crude extract's volume). The organic and aqueous layers were separated by centrifugation. The upper layer was removed and the extract was rinsed 2 times with $0.02 \% \mathrm{CaCl}_{2}$ solution in methanol ( 0.15 of the crude extract's volume). The lower layer was dried with a stream of nitrogen and the extracts were further dried overnight in a vacuum desiccator. After extraction, $0.01 \%$ butylated hydroxyl toluene (BHT) was added as an antioxidant. Fatty acid methyl esters (FAMEs) of lipids were prepared and determined as follows: $2 \% \mathrm{H}_{2} \mathrm{SO}_{4}$ in methanol was added to the lipid extract, and the solution was incubated in an oven at $80^{\circ} \mathrm{C}$ for $2 \mathrm{~h}$ for esterification. After cooling, $1 \mathrm{ml}$ distilled water and $2 \mathrm{ml}$ petroleum ether were added to the tube and mixed in vortex. The upper organic layer was transferred to a vial and dried by a nitrogen stream. FAMEs were analyzed by gas chromatography (GC) on a fused silica column for polyunsaturated fatty acid (Supelco SPB-PUFA, $30 \times$ $0.32 \mathrm{~mm}$ ID, $0.20 \mu \mathrm{m}$ film) in a Hewlett Packard model 6890 Series GC system fitted with an autosampler (Agilent 6890 Series Injector) and equipped with flame ionization detector (GC-FID). Authentic methylated fatty acid standards were purchased from Supelco and Alltech. Under our GC conditions as described below, the FAME peaks on the GC graph were well separated and easily identified: non-FAME impurities did not interfere with the identifications. Hence, no post-transesterification purification by thin-layer chromatography (TLC) was carried out. The peak identifications of the standard fatty acids were checked by GC-MS for confirmation. Methyl nonadecanoate (19:0) was used as internal standard and the carrier gas was helium with speed of $25 \mathrm{~cm} \mathrm{~s}^{-1}$. The operating conditions for the GC-FID were as follows: initial column temperature was $50^{\circ} \mathrm{C}$ for $2 \mathrm{~min}$, and was then increased to $210^{\circ} \mathrm{C}$ at $4^{\circ} \mathrm{C} \mathrm{min}^{-1}$. The detector was held at $260^{\circ} \mathrm{C}$, the injector temperature was $250^{\circ} \mathrm{C}$, and the split ratio was 1:50. The fatty acids were identified by their retention time with reference to those of the standards.

Statistical analysis and isotope mixing model. Differences in environmental conditions, carbon and nitrogen stable isotope ratios and fatty acid markers between the experimental site in the fish culture zone and the reference site were compared with Student's t-test. ANOVA with Tukey's test for multiple comparisons was used to compare the isotopic values of potential food sources, i.e. POM, fish feed and fish faeces (Zar 1999). Prior to analysis, raw data were diagnosed for normality of distribution and homogeneity of variance with KolmogorovSmirnov test and Levene's test, respectively. Fatty acid profiles of mussel tissue and corresponding potential food sources were analyzed using multivariate principal component analysis (PCA). All statistical analyses were performed with the software SPSS for Windows, Release 9.0 (SPSS 1999a,b).

In the present study, potential food sources of the mussels at the experimental site in the fish raft area included POM, fish feed residues and fish faeces. Hence, a 3 end-member concentration-weighted isotope mixing model (Philips 2001, Philips \& Koch 2002) was used to evaluate the respective contribution of the food sources to the diet of the mussels that were cultured in fish cages, as follows: 


$$
\begin{aligned}
& \left(\delta^{13} \mathrm{C}^{\prime}{ }_{X}-\delta^{13} \mathrm{C}_{M}\right)[\mathrm{C}]_{X} f_{X, B}+\left(\delta^{13} \mathrm{C}^{\prime}{ }_{Y}-\delta^{13} \mathrm{C}_{M}\right)[\mathrm{C}]_{Y} f_{Y, B} \\
& \quad+\left(\delta^{13} \mathrm{C}^{\prime}{ }_{Z}-\delta^{13} \mathrm{C}_{M}\right)[\mathrm{C}]_{Z} f_{Z, B}=0 \\
& \left(\delta^{15} \mathrm{~N}^{\prime}{ }_{X}-\delta^{15} \mathrm{~N}_{M}\right)[\mathrm{N}]_{X} f_{X, B}+\left(\delta^{15} \mathrm{~N}^{\prime}{ }_{Y}-\delta^{15} \mathrm{~N}_{M}\right)[\mathrm{N}]_{Y} f_{Y, B} \\
& \quad+\left(\delta^{15} \mathrm{~N}_{Z}{ }_{Z}-\delta^{15} \mathrm{~N}_{M}\right)[\mathrm{N}]_{Z} f_{Z, B}=0 \\
& f_{X, B}+f_{Y, B}+f_{Z, B}=1
\end{aligned}
$$

where $f_{X, B}, f_{Y, B}$ and $f_{Z, B}$ represent the fractions of assimilated biomass $(B)$ of sources $X, Y$, and $Z$, respectively, in the mixture $M .[C]_{\mathrm{X}},[\mathrm{C}]_{\mathrm{Y}},[\mathrm{C}]_{\mathrm{Z}}[\mathrm{N}]_{\mathrm{X}},[\mathrm{N}]_{\mathrm{Y}}$, and $[N]_{Z}$ represent the $\mathrm{C}$ and $\mathrm{N}$ concentrations in food sources $X, Y$, and $Z$. Isotopic signatures for the sources were corrected for trophic fractionation as designated by the prime (') symbol. Average fractionation effects of 1 and $3 \%$ for carbon and nitrogen isotopes, respectively, were used to correct stable isotope shifts for each trophic level (Peterson \& Fry 1987, McClelland \& Valiela 1998).

\section{RESULTS}

\section{Environmental conditions}

A comparison of environmental conditions at the experimental and reference sites, including chl $a$ and current speed in the surface 2 to $3 \mathrm{~m}$ of the water column, are summarized in Table 1. All parameters recorded at the experimental site in the fish culture zone were significantly lower than those at the reference site (Student's $t$-test, $\mathrm{p}<0.05$ ). Current speed ranged from 0.4 to $5.6 \mathrm{~cm} \mathrm{~s}^{-1}$ and 2.3 to $51.5 \mathrm{~cm} \mathrm{~s}^{-1}$ at the experimental and reference sites, respectively, with an average residual current velocity of $0.35 \mathrm{~cm} \mathrm{~s}^{-1}$ at the experimental site and $8.62 \mathrm{~cm} \mathrm{~s}^{-1}$ at the reference site. In general, the current flowed in a main direction from east to west from the inside of the embayment towards open waters during both flood and ebb tides.

\section{Isotopic compositions of mussel tissue and food sources}

$\delta^{13} \mathrm{C}$ values of mussel tissue from the experimental site in the fish raft zone and the reference site were $-19.3 \pm 0.3 \%$ o $(n=3)$ and $-20.6 \pm 0.3 \%$ o $(n=3)$, respectively. For $\delta^{15} \mathrm{~N}$, the values from the experimental and reference sites were $10.5 \pm 0.3 \%$ o $(\mathrm{n}=3)$ and $8.6 \pm 0.2 \%$ o $(n=3)$, respectively. For the potential food sources that we investigated, i.e. POM, fish feed residue and fish faeces, $\delta^{13} \mathrm{C}$ and $\delta^{15} \mathrm{~N}$ values as well as results of ANOVA among the food sources are listed in Table 2. Isotopic signatures of the 3 potential food sources from the experimental site in the fish raft zone were significantly different, except for the $\delta^{13} \mathrm{C}$ values of fish feed and fish faeces.
Table 1. Comparison of environmental conditions between the experimental site in the fish culture zone and the reference site. Values are mean $\pm 1 \mathrm{SD}$

\begin{tabular}{|lcc|}
\hline Parameter & Chl a $\left(\mu \mathrm{g} \mathrm{l}^{-1}\right)$ & Current speed $\left(\mathrm{cm} \mathrm{s}^{-1}\right)$ \\
\hline Experimental site & $1.88 \pm 0.19$ & $1.32 \pm 0.63$ \\
Reference site & $2.48 \pm 0.11$ & $23.33 \pm 2.47$ \\
$\mathrm{df}$ & 4 & 18 \\
$t$ & -4.73 & -27.32 \\
$\mathrm{p}$ & $<0.01$ & $<0.001$ \\
\hline
\end{tabular}

Enrichment of heavy stable carbon $\left({ }^{13} \mathrm{C}\right)$ and nitrogen $\left({ }^{15} \mathrm{~N}\right)$ isotopes in mussel tissue at the experimental site in the fish culture zone relative to the reference site was significant (Student's $t$-test: for $\delta^{13} C_{1}-19.3 \%$ vs. $-20.6 \%$ o, $t_{4}=7.02, \mathrm{p}<0.005$; for $\delta^{15} \mathrm{~N}, 10.5 \%$ vs. $\left.8.6 \%, t_{4}=10.34, \mathrm{p}<0.001\right)$. However, $\delta^{13} \mathrm{C}$ and $\delta^{15} \mathrm{~N}$ values of POM from the experimental site in the fish raft zone and the reference site were statistically similar. For $\delta^{13} \mathrm{C}$, values from the experimental and reference sites were -21.8 and $-21.6 \%$, respectively $\left(t_{4}=\right.$ $-2.4, \mathrm{p}=0.08$ ). For $\delta^{15} \mathrm{~N}$, respective values were 5.5 and $5.6 \%\left(t_{3}=-0.4, \mathrm{p}=0.70\right)$. A dual isotope plot (Fig. 1) clearly demonstrated the incorporation of the 3 potential food sources into the mussel tissue. Taking into account the carbon and nitrogen concentrations of the food sources (Table 2), results calculated with the 3 end-member concentration-weighted dual isotope mixing model estimated that the contribution of POM, fish feed and fish faeces to the mussel dietary consumption was $68.3,27.5$ and $4.2 \%$, respectively.

\section{Fatty acid profiles of mussel tissue and food sources}

The fatty acid profiles of mussel tissue and food sources are summarized in Table 3. Results of the PCA ordination plot (Fig. 2) showed that the fatty acid pro-

Table 2. Carbon and nitrogen content and $\delta^{13} \mathrm{C}$ and $\delta^{15} \mathrm{~N}$ values of potential food sources (particulate organic matter [POM], fish feed residue and fish faeces). Values are mean \pm $1 \mathrm{SD}(\mathrm{n}=3) \cdot \delta^{13} \mathrm{C}$ and $\delta^{15} \mathrm{~N}$ values of food sources compared using ANOVA with Tukey's test for multiple comparisons; Within columns, values with the same superscript letter are not significantly different $(\mathrm{p}<0.05)$

\begin{tabular}{|lcccc|}
\hline $\begin{array}{l}\text { Food } \\
\text { sources }\end{array}$ & $\begin{array}{c}\text { C content } \\
(\%)\end{array}$ & $\begin{array}{c}\mathrm{N} \text { content } \\
(\%)\end{array}$ & $\begin{array}{c}\delta^{13} \mathrm{C} \\
(\%)\end{array}$ & $\begin{array}{c}\delta^{15} \mathrm{~N} \\
(\%)\end{array}$ \\
\hline POM & $23.52 \pm 1.56$ & $4.50 \pm 0.32$ & $-21.8 \pm 0.1^{\mathrm{a}}$ & $5.5 \pm 0.3^{\mathrm{a}}$ \\
Fish feed & $41.35 \pm 1.89$ & $9.02 \pm 0.33$ & $-18.6 \pm 0.0^{\mathrm{b}}$ & $9.8 \pm 0.2^{\mathrm{b}}$ \\
Fish faeces & $28.06 \pm 0.86$ & $2.93 \pm 0.13$ & $-18.1 \pm 0.7^{\mathrm{b}}$ & $11.3 \pm 0.2^{\mathrm{c}}$ \\
\hline
\end{tabular}




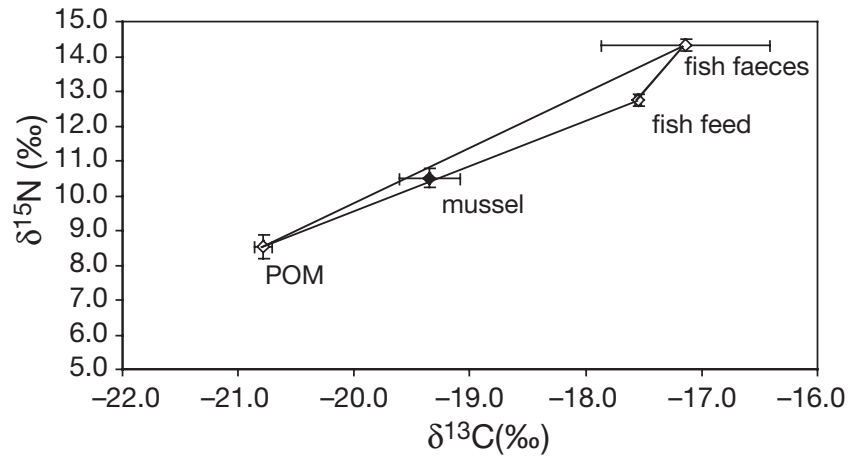

Fig. 1. Dual isotope plot of mussel tissue and potential food sources at the experimental site. Average fractionation effects of $1 \%$ and $3 \%$ for carbon and nitrogen, respectively, were used to correct stable isotope shifts between trophic levels

files of POM from the experimental site in the fish raft zone and the reference site largely overlapped with each other. However, the fatty acid profiles of mussel tissue from the experimental and reference sites were classified into 2 separate groups in the PCA plot. More- over, when comparing with mussels from the reference site, the centroid of fatty acid data for mussels collected from the experimental site in the fish raft zone was nearer to those data derived from fish feed. The fatty acid profiles of fish faeces were further away from those of mussel tissue.

The proportions of fatty acids that are known to be important for energetic requirements in marine organisms were compared between mussels collected from the experimental site and those from the reference site (Table 3). For 14:0, 18:0 and 18:1n9, the concentration of these 3 fatty acids in fish feed was higher than that in POM at the 2 sites (ANOVA: for 14:0, $F_{2,22}=80.3, \mathrm{p}<$ 0.01 ; for $18: 0, F_{2,22}=119.5, \mathrm{p}<0.01$; for $18: 1 n 9, F_{2,22}=$ 1036.2, $\mathrm{p}<0.01$ ), and the corresponding concentration in mussel tissue collected from the experimental site was accordingly higher than that of mussels from the reference site (Student's $t$-test: for 14:0, $t_{16}=14.1, \mathrm{p}<$ 0.01 ; for 18:0, $t_{16}=14.2, \mathrm{p}<0.01$; for $18: 1 n 9, t_{16}=3.0$, $p<0.01$ ). In contrast, the concentration of $20: 5 n 3$ in mussel tissue from the experimental site was lower

Table 3. Fatty acid profiles (\%) of mussels at experimental and reference sites, and of potential food sources $(\mathrm{n}=3$ to 9$)$. MES = mussels at experimental site; MRS = mussels at reference site; PES = POM at experimental site; PRS = POM at reference site; $\mathrm{FFD}=$ fish feed $; \mathrm{FFC}=$ fish faeces

\begin{tabular}{|c|c|c|c|c|c|c|}
\hline Fatty acid & MES & MRS & PES & PRS & FFD & $\mathrm{FFC}$ \\
\hline \multicolumn{7}{|c|}{ Saturated fatty acids } \\
\hline 11:0 & 0.00 & 0.00 & 0.00 & 0.00 & $0.01 \pm 0.00$ & 0.00 \\
\hline $12: 0$ & 0.00 & 0.01 & 0.00 & 0.00 & $0.17 \pm 0.02$ & 0.00 \\
\hline $14: 0$ & $7.55 \pm 0.51$ & $5.96 \pm 0.45$ & $3.41 \pm 0.35$ & $3.06 \pm 0.22$ & $5.27 \pm 0.88$ & $1.17 \pm 0.68$ \\
\hline $15: 0$ & $0.90 \pm 0.22$ & $0.71 \pm 0.03$ & $0.24 \pm 0.02$ & $0.42 \pm 0.09$ & $0.72 \pm 0.06$ & $0.23 \pm 0.01$ \\
\hline $16: 0$ & $30.31 \pm 3.82$ & $35.04 \pm 3.22$ & $29.41 \pm 2.33$ & $24.34 \pm 2.15$ & $32.70 \pm 1.66$ & $8.80 \pm 1.11$ \\
\hline $18: 0$ & $10.59 \pm 0.78$ & $7.53 \pm 0.46$ & $2.48 \pm 0.30$ & $4.26 \pm 0.48$ & $9.16 \pm 1.10$ & $7.72 \pm 0.35$ \\
\hline $17: 0$ & $1.73 \pm 0.55$ & $2.36 \pm 0.55$ & $0.46 \pm 0.03$ & $0.90 \pm 0.08$ & $1.01 \pm 0.05$ & $0.41 \pm 0.02$ \\
\hline $20: 0$ & $0.97 \pm 0.08$ & $0.55 \pm 0.06$ & $0.49 \pm 0.07$ & 0.00 & $0.83 \pm 0.07$ & $0.75 \pm 0.06$ \\
\hline $21: 0$ & $0.13 \pm 0.01$ & $0.76 \pm 0.05$ & 0.00 & 0.02 & 0.00 & $1.24 \pm 0.16$ \\
\hline $22: 0$ & 0.00 & 0.00 & $0.24 \pm 0.01$ & 0.00 & 0.00 & 0.00 \\
\hline Subtotal & $52.18 \pm 1.85$ & $52.92 \pm 1.66$ & $36.72 \pm 1.58$ & $33.00 \pm 1.55$ & $49.87 \pm 1.34$ & $20.32 \pm 1.22$ \\
\hline \multicolumn{7}{|c|}{ Monounsaturated fatty acids } \\
\hline $15: 1 n 5$ & 0.00 & 0.00 & $0.84 \pm 0.03$ & $1.79 \pm 0.01$ & 0.04 & 0.00 \\
\hline $17: 1 n 7$ & $0.21 \pm 0.01$ & $0.68 \pm 0.02$ & $3.16 \pm 0.16$ & $7.25 \pm 0.22$ & $0.60 \pm 0.03$ & $0.64 \pm 0.03$ \\
\hline $16: 1 n 7$ & $10.65 \pm 0.68$ & $8.47 \pm 0.56$ & $17.76 \pm 1.23$ & $17.73 \pm 1.33$ & $8.28 \pm 1.02$ & $8.67 \pm 0.89$ \\
\hline $18: 1 n 9$ & $4.66 \pm 0.16$ & $2.27 \pm 0.09$ & $2.38 \pm 0.09$ & $2.11 \pm 0.11$ & $12.75 \pm 1.35$ & $24.86 \pm 1.88$ \\
\hline $18: 1 n 7$ & $3.85 \pm 0.11$ & $3.52 \pm 0.15$ & $7.67 \pm 0.22$ & $9.78 \pm 0.36$ & $3.89 \pm 0.11$ & $3.55 \pm 0.15$ \\
\hline $20: 1 n 9$ & $2.35 \pm 0.08$ & $3.21 \pm 0.18$ & 0.00 & 0.00 & $0.16 \pm 0.02$ & 0.00 \\
\hline $22: 1 n 9$ & $0.45 \pm 0.05$ & $0.61 \pm 0.03$ & 0.00 & 0.00 & 0.00 & $0.39 \pm 0.05$ \\
\hline Subtotal & $22.16 \pm 1.55$ & $18.75 \pm 1.63$ & $31.80 \pm 2.15$ & $38.66 \pm 2.30$ & $25.71 \pm 2.10$ & $38.11 \pm 1.59$ \\
\hline \multicolumn{7}{|c|}{ Polyunsaturated fatty acids } \\
\hline $18: 2 n 6$ & $1.46 \pm 0.12$ & $1.50 \pm 1.08$ & $1.58 \pm 0.15$ & $0.35 \pm 0.01$ & $0.91 \pm 0.09$ & $1.47 \pm 0.12$ \\
\hline $18: 3 n 6$ & $0.20 \pm 0.01$ & 0.00 & 0.00 & 0.00 & 0.05 & $0.28 \pm 0.01$ \\
\hline $20: 2 n 6$ & $0.72 \pm 0.03$ & $0.48 \pm 0.05$ & $0.21 \pm 0.02$ & 0.00 & 0.00 & 0.00 \\
\hline $20: 3 n 3$ & $0.14 \pm 0.01$ & $0.20 \pm 0.01$ & $0.21 \pm 0.01$ & 0.00 & 0.00 & 0.00 \\
\hline $20: 4 n 6$ & $3.30 \pm 0.22$ & $2.97 \pm 0.36$ & $0.77 \pm 0.05$ & 0.00 & $3.42 \pm 0.25$ & $5.26 \pm 0.26$ \\
\hline $20: 5 n 3$ & $8.24 \pm 0.22$ & $12.21 \pm 1.23$ & $16.06 \pm 1.25$ & $14.37 \pm 1.36$ & $7.00 \pm 0.79$ & $7.74 \pm 0.88$ \\
\hline $22: 2 n 6$ & 0.00 & $0.92 \pm 0.05$ & $0.25 \pm 0.02$ & 0.00 & 0.00 & 0.00 \\
\hline $22: 6 n 3$ & $11.59 \pm 0.98$ & $10.04 \pm 0.88$ & $12.41 \pm 1.23$ & $13.62 \pm 1.33$ & $13.07 \pm 1.56$ & $26.84 \pm 2.32$ \\
\hline Subtotal & $25.66 \pm 1.52$ & $28.32 \pm 2.21$ & $31.48 \pm 3.32$ & $28.34 \pm 2.35$ & $24.45 \pm 2.01$ & $41.59 \pm 3.32$ \\
\hline
\end{tabular}




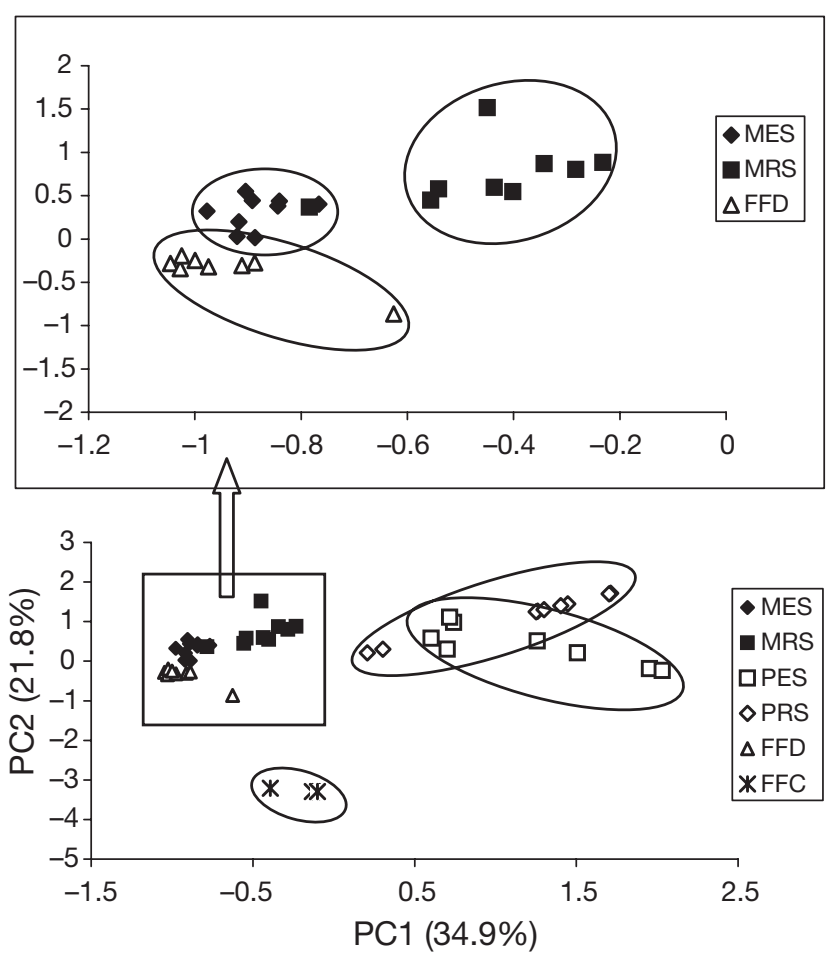

Fig. 2. PCA ordination plots of fatty acid profiles from mussel tissue and potential food sources. Inserted diagram is enlargement of the framed area of the PCA plot, showing relationships between fatty acid profiles of mussel tissue from both sampling sites and fish feed. Bracketed numbers are percentages of variance in fatty acid profiles explained by Principle Components 1 (PC1) and 2 (PC2). MES = mussels at experimental site; MRS $=$ mussels at reference site; $\mathrm{PES}=$ $\mathrm{POM}$ at experimental site; $\mathrm{PRS}=\mathrm{POM}$ at reference site; $\mathrm{FFD}=$ fish feed $; \mathrm{FFC}=$ fish faeces

than that in mussels from the reference site (Student's $t$-test, $t_{16}=-5.1, \mathrm{p}<0.01$ ) as a result of 'dilution' by fish feed, which contained a lower concentration of 20:5n3 than the POM (ANOVA: $F_{2,22}=40.5, \mathrm{p}<0.01$ ).

It appeared that $16: 0$ and $18: 1 n 7$ concentration in mussel tissue did not show a significant difference between the experimental and reference sites (Student's $t$-test: for 16:0, $t_{16}=-1.7, \mathrm{p}=0.11$; for 18:1n7, $t_{16}=1.2, \mathrm{p}=0.24$ ) despite the different concentration of these 2 acids in fish feed and POM. The 22:6n3 concentration in fish feed and POM did not show a significant difference (ANOVA: $F_{2,22}=0.7, \mathrm{p}=0.51$ ). Consequently, the concentration of this fatty acid in mussel tissue collected at both the experimental and reference sites was similar (Student's $t$-test, $t_{16}=1.0, \mathrm{p}=0.33$ ).

For the odd carbon numbered fatty acids 15:0, 17:0, $15: 1 n 5$ and $17: 1 n 7$, the concentrations of these 4 acids in POM at the reference site were all higher than those at the experimental site (Student's $t$-test: for 15:0, $t_{15}=2.2, \mathrm{p}<0.05 ;$ for $17: 0, t_{15}=2.2, \mathrm{p}<0.05$; for 15:1n5, $t_{15}=2.3, \mathrm{p}<0.05$; for $\left.17: 1 \mathrm{n} 7, t_{15}=2.4, \mathrm{p}<0.05\right)$. As a re- sult, the concentrations of $17: 0$ and $17: 1 n 7$ in mussels from the reference site were higher than those in mussels from the experimental site (Student's $t$-test: for $17: 0, t_{16}=4.8, \mathrm{p}<0.01$; for 17:1n7, $\left.t_{16}=4.8, \mathrm{p}<0.05\right)$, while the concentration of 15:0 in mussels from the experimental site was not significantly different to those from the reference site (Student's $t$-test, $t_{16}=1.9, \mathrm{p}=$ 0.08). The fatty acid 15:1n5 was undetectable in mussel tissue from both the experiment and reference sites.

\section{DISCUSSION}

In the present study, isotopic signatures of the 3 potential food sources for mussels at the experimental site in the fish raft zone were significantly different, except for the $\delta^{13} \mathrm{C}$ values of fish feed and fish faeces. Such isotopic differences implied the feasibility and possibility of tracing the combinations of these food sources taken up by mussels (Peterson \& Fry 1987). The $\delta^{13} \mathrm{C}$ and $\delta^{15} \mathrm{~N}$ values of POM, which is the principal food source of mussels, were within those of marine source POM reported by other studies (Fry 1988, Yokoyama \& Ishihi 2003). It is widely accepted and shown that while there is little or no shift in ${ }^{13} \mathrm{C}$ content when nutrients are transferred through food chains (Fry \& Sherr 1984), there is significant enrichment of ${ }^{15} \mathrm{~N}$ in the tissue of predators with a $\delta$ value ca. $3 \%$ relative to their diet acquisition (Owens 1987 and references therein). The dispersion of fish farming waste is quite localized around fish cages, and generally does not exceed $100 \mathrm{~m}$ (Ye et al. 1991, Wu et al. 1994). Therefore, at the reference site in the present experiment, where the main diet of mussels was exclusively assumed to be POM, the average $\delta^{13} \mathrm{C}_{\text {mussel }}-\delta^{13} \mathrm{C}_{\mathrm{POM}}$ and $\delta^{15} \mathrm{~N}_{\text {mussel }}-\delta^{15} \mathrm{~N}_{\text {POM }}$ were $1.0 \%$ and $3.0 \%$, respectively. This confirms the assumption of $1 \%$ carbon and $3 \%$ nitrogen isotopic shifts used in the isotope mixing model.

At the experimental site in the fish raft zone, the cultured fish are fed with small trash fish, which are isotopically heavier than POM due to their planktotrophic foraging habit (Focken 2001). Relative to fish feed, ${ }^{13} \mathrm{C}$ of faeces egested by the cultured fish is slightly, but not significantly, enriched (-18.6\% vs. $-18.1 \%$ o); in contrast, ${ }^{15} \mathrm{~N}$ in fish faeces is significantly enriched relative to fish feed due to the preferential absorption of isotopically light ${ }^{14} \mathrm{~N}$ during the digestion process (Checkley \& Entzeroth 1985, Peterson \& Fry 1987). Therefore, the distinct isotope signatures resulting from isotopic fractionation along the pathway from POM to planktivorous fish and then to fish faeces provide an opportunity to quantify the contribution of these potential foods to mussels using stable isotopes as trophic markers. Since the mussels in this study 
were transplanted from the same population, the assumption of homogeneity of initial isotopic value would be valid. Moreover, statistical test results showed that POM did not differ significantly between the experimental and reference sites in terms of carbon and nitrogen isotopic ratios.

It might be speculated that the enrichment of ${ }^{13} \mathrm{C}$ and ${ }^{15} \mathrm{~N}$ in mussels collected from the experimental site relative to those from the reference site resulted from the consumption of isotopically heavier fish remains and faeces, provided that other potential food sources were excluded. Grey et al. (2004) studied the availability of fish farm waste to the zooplanktonic and pelagic communities with carbon and nitrogen isotope analyses. Their results, derived from a simple isotope mixing model, revealed that the contributions of salmonid farm waste to cladoceran, roach and chironomid larvae might be as much as 65, 80 and $50 \%$, respectively. In an experiment similar to our present study, Yokoyama et al. (2002) quantified that the contribution ratio of shrimp feed (the main components of which were fish meal and flour) to the diet of epibenthic greenlipped mussels might reach $90 \%$. In the experiment of Yokoyama et al. (2002), shrimp were reared by feeding dry pellets made of fish meal and flour. Their setup increased the accessibility of shrimp farming waste to the mussels through direct deposition, and the use of powdered fish meal enhanced the digestibility of the waste. As a result, the contribution of shrimp farming waste to the mussel ration was higher than that reported in our present study.

Fatty acid composition of animal tissue can reflect the diets of the animals if they are fed in relatively stable food aliquots to satiation (Sargent et al. 1987). This also applies to bivalves, which assimilate fatty acids in proportion to the fatty acid composition in their diet (Budge et al. 2001). Hence, potential trophic sources could be traced through the comparison of fatty acid profiles of mussels between different food conditions. In the present study, the fatty acid profiles of POM from the experimental site in the fish raft zone and the reference site were quite similar, indicating the identical nature of POM derived from these 2 sites. However, the points representing the fatty acid profiles of fish faeces were located further away from those of mussel tissue and POM in the PCA plot, which suggested that there were considerable changes in fatty acid composition during the digestion process in cultured fish. Moreover, the clear separation of the fatty acid profiles of fish faeces from those of mussel tissue and POM in the PCA plot implied that the contribution of fish faeces to mussel dietary consumption was relatively minimal. This is consistent with the small contribution of $4.2 \%$ from fish faeces to uptake by the mussels evident from stable isotope data.
Because the fatty acid profiles of POM and fish feed were quite different, the comparison of fatty acid profiles (in terms of both the overall pattern and single fatty acids) between mussels from the experimental and reference sites indicated that mussels at the experimental site in the fish culture zone did acquire their fatty acid signature from uneaten fish feed. The comparison of fatty acids important for energetic requirements of marine organisms further confirmed that fish feed influenced the fatty acid composition of mussels from the experimental site. For example, 14:0, 18:0 and $18: 1 n 9$ in mussel tissue from the experimental site were in significantly higher concentrations than in tissue from the reference site, and such high levels corresponded to those in fish feed as compared to levels in POM.

Generally, the composition of POM is dominated by phytoplankton, bacteria and sedimentary matter resuspended from seabed. It is technically difficult to separate specific POM components for isotopic or fatty acid measurements. However, fatty acids with odd numbers of carbon atoms may act as bacterial markers (Dalsgaard et al. 2003), and thus provide evidence for the consumption of bacterial matter by mussels (Budge et al. 2001). In our study, elevated concentrations of odd-numbered-carbon fatty acids 17:0 and 17:1n7 in POM and mussel tissue were noted at the reference site. In view of faster current flow at this site relative to that at the experimental fish farm site, such high concentrations might reflect consumption of resuspended sedimentary bacteria in the water column by the mussels over the study period. Resuspension of the seabed sediment was also demonstrated by the elevated level of particulate inorganic matter in winter due to the strong monsoon effects (Gao 2005).

The present study did not examine feeding physiological processes of filter-feeding bivalves at the experimental site. Considerable work on feeding, digestion and absorption processes of bivalve mussels has been intensively documented (e.g. Bayne 1976, Bayne et al. 1993, Wong \& Cheung 1999, 2001, 2003, Gao et al. 2002). Results from conventional gut content analysis (Berg \& Newell 1986) or stable isotope and fatty acid trophic marker methods (Freites et al. 2002, Page \& Lastra 2003) suggest that feeding by mussels is opportunistic in nature, and is dependent on food availability. In turn, food availability is subject to seasonal or spatial fluctuations. Furthermore, the rapid acclimation of physiological and enzymatic activities of mussels to new food conditions demonstrates the regulation and flexibility of feeding modes in these bivalves (Kreeger \& Newell 2001, Wong \& Cheung 2003).

Generally, mussels are regarded as herbivorous feeders (Page \& Hubbard 1987). However, mussels can 
be carnivores or omnivores under some circumstances (Wong \& Levinton 2003). Studies showed that mussels could utilize non-phytoplankton matter as food sources to meet part of their energy requirements, particularly when phytoplankton concentration was too low to provide an adequate food ration (Langdon \& Newell 1990, Page \& Lastra 2003, Wong \& Levinton 2004). In addition, omnivorous bivalves usually exhibit a better growth performance and metabolism than exclusively herbivorous bivalves (Baldwin \& Newell 1991, Wong \& Levinton 2004). Fish farms do not always enhance phytoplankton production relative to adjacent waters. For example, Taylor et al. (1992) observed that chl a levels fluctuated with distance from fish farms in a pattern that totally contrasted with predicted hypothesis: chlorophyll concentration became gradually elevated with increasing distance from fish farms, and resulted in a lower condition index (ratio of dry tissue weight to dry shell weight) in mussels at a sampling site $3 \mathrm{~m}$ from the fish cages relative to sites that were $15 \mathrm{~m}$ and $75 \mathrm{~m}$ away. Taylor et al. (1992) speculated that phytoplankton production inside fish cages was not noticeably augmented due to rapid flushing.

Widdows et al. (1979) found that the minimum maintenance ration of Mytilus edulis was $\sim 2.4 \mu \mathrm{g} \mathrm{l}^{-1} \mathrm{chl} \mathrm{a}$, above which food availability could support positive growth in bivalves. The results of Widdows et al. (1979) implied that a chl a level of $2.4 \mu \mathrm{g} \mathrm{l}^{-1}$ was too low to meet the dietary requirements of this species. In our study, the topography of the embayment and presence of fish rafts considerably reduced water exchange and inhibited allochthonous nutrient inputs as well as autochthonous nutrient upwelling from seabed sediments in the fish raft area (Pearson \& Black 2001). As a result, the phytoplankton concentration was reduced at the fish culture zone, as indicated by a chl a level that was lower than that at the reference site (1.88 vs. $2.48 \mathrm{\mu g} \mathrm{l}^{-1}$ ); this value from the fish culture zone was lower than Widdows et al. (1979)'s threshold value of $2.4 \mathrm{\mu g} \mathrm{l}^{-1}$.

Our experiment was conducted in September to December, i.e. during the dry, winter season, prior to algal blooms that occur from spring to summer (Hodgkiss $\&$ Lu 2004). This may have further reduced the availability of phytoplankton (POM) as a food source in the fish raft zone during our study. As a strategy to combat a shortage of food supply, mussels may consume fish feed or fish faeces as alternative nutrition sources, through either active acquisition or passive force-feeding when exposed to potential food sources. In addition, the reduced current velocity in the fish culture zone (owing to the presence of fish rafts and associated facilities) enhances the residence time of coarse trash fish particles within fish cages and increases the opportunity for mussels to take up such particles.
Acknowledgements. This research was fully supported by a Strategic Research Grant (No. 7001691) from City University of Hong Kong and in part by the Chinese Academy of Sciences through the 'Bairen Project' programme. We thank $\mathrm{L}$. Li of the Stable Isotope Laboratory for Ecological and Environmental Research, Institute of Botany, the Chinese Academy of Sciences, China for his assistance with stable isotope analyses.

\section{LITERATURE CITED}

Baldwin BS, Newell RIE (1991) Omnivorous feeding by planktotrophic larvae of the Eastern oyster Crassostrea virginica. Mar Ecol Prog Ser 78:285-301

Bayne BL (1976) Marine mussels: their ecology and physiology. Cambridge University Press, Cambridge

Bayne BL, Iglesias JIP, Hawkins AJS, Navarro E, Heral M, Deslous-Paoli JM (1993) Feeding behaviour of the mussel, Mytilus edulis: response to variations in quantity and organic content of the seston. J Mar Biol Assoc UK 73: 813-829

Bearhop S, Waldron S, Thompson D, Furness R (2000) Bioamplification of mercury in great skua Catharacta skua chicks: the influence of trophic status as determined by stable isotope signatures of blood and feathers. Mar Pollut Bull 40:181-185

Berg JA, Newell RIE (1986) Temporal and spatial variations in the composition of seston available to the suspension feeder Crassostrea virginica. Estuar Coast Shelf Sci 23: 375-386

Bligh EG, Dyer WJ (1959) A rapid method of total lipid extraction and purification. Can J Biochem Physiol 37:911-917

Budge SM, Parrish CC, Mckenzie CH (2001) Fatty acid composition of phytoplankton, settling particulate matter and sediments at a sheltered bivalve aquaculture site. Mar Chem 76:285-303

Canuel EA, Cloern JE, Ringelberg DB, Guckert JB (1995) Molecular and isotopic tracers used to examine sources of organic matter and its incorporation into the food webs of San Francisco Bay. Limnol Oceanogr 40:67-81

Checkley DM, Entzeroth LC (1985) Elemental and isotopic fractionation of carbon and nitrogen by marine, planktonic copepods and implications to the marine nitrogen cycle. J Plankton Res 7:553-568

Cheung SG (1991) Energetics of transplanted populations of the green-lipped mussel Perna viridis (Linnaeus) (Bivalve: Mytilacea) in Hong Kong. I: Growth, condition and reproduction. Asian Mar Biol 8:117-131

Collier KJ, Bury S, Gibbs M (2002) A stable isotope study of linkages between stream and terrestrial food webs through spider predation. Freshw Biol 47:1651-1659

Currin CA, Newell SY, Paerl HW (1995) The role of standing dead Spartina alterniflora and benthic microalgae in sail marsh food webs: considerations based on multiple stable isotope analysis. Mar Ecol Prog Ser 121: 99-116

Dalsgaard J, St John M, Kattner G, Muller-Navarra D, Hagen W (2003) Fatty acid trophic markers in the pelagic marine environment. Adv Mar Biol 46:225-340

Dame RF (1993) Bivalve filter feeders in estuarine and coastal ecosystem processes. Springer Verlag, Berlin

Dame RF (1996) Ecology of marine bivalves: an ecosystem approach. CRC Press, Boca Raton, FL

Focken U (2001) Stable isotopes in animal ecology: the effect of ration size on the trophic shift of $\mathrm{C}$ and $\mathrm{C}$ isotopes between feed and carcass. Isotopes Environ Health Stud 37:199-211 
Folke C, Kautsky N (1989) The role of ecosystems for a sustainable development of aquaculture. Ambio 18:234-243

Freites L, Labarta U, Fernández-Reiriz MJ (2002) Evolution of fatty acid profiles of subtidal and rocky shore mussel seed (Mytilus galloprovincialis, Lmk.). Influence of environmental parameters. J Exp Mar Biol Ecol 268:185-204

Fry B (1988) Food web structure on Georges Bank from stable C, N and S isotopic compositions. Limnol Oceanogr 33: $1182-1190$

Fry B, Sherr EB (1984) $\delta^{13} \mathrm{C}$ measurements as indicators of carbon flow in marine and freshwater ecosystems. Contrib Mar Sci 27:13-47

Gao QF (2005) Use of artificial reefs and green-lipped mussels (Perna viridis) for removal of nutrients from marine fish farming. PhD thesis, City University of Hong Kong

Gao QF, Wang ZL, Wong WH, Cheung SG (2002) Effects of food quality and quantity on feeding and absorption in black-ribbed mussels, Septifer virgatus (Wiegmann) (Bivalvia: Mytilidae) dominating wave-exposed habitats in Hong Kong. J Shellfish Res 21:51-57

Gao QF, Cheung KL, Cheung SG, Shin PKS (2005) Effects of nutrient enrichment derived from fish farming activities on marcoinvertebrate assemblages in a subtropical region of Hong Kong. Mar Pollut Bull 51:994-1002

Gowen RJ, Bradbury NB (1987) The ecological impact of salmonid farming in coastal waters: a review. Oceanogr Mar Biol Annu Rev 25:563-575

Grey J, Waldron S, Hutchinson R (2004) The utility of carbon and nitrogen isotope analyses to trace contributions from fish farms to the receiving communities of freshwater lakes: a pilot study in Esthwaite Water, UK. Hydrobiologia 524:253-262

Guo X, Ford SE, Zhang F (1999) Molluscan aquaculture in China. J Shellfish Res 18:19?31

Hobson KA, Welch HE (1992) Determination of trophic relationships within a high Arctic marine food web using $\delta^{13} \mathrm{C}$ and $\delta^{15} \mathrm{~N}$ analysis. Mar Ecol Prog Ser 84:9-18

Hodgkiss IJ, Lu S (2004) The effects of nutrients and their ratios on phytoplankton abundance in Junk Bay, Hong Kong. Hydrobiologia 512:215-229

Huang ZG, Lee SY, Mak PMS (1985) The distribution and population structure of Perna viridis (Bivalvia: Mytilacea) in Hong Kong waters. In: Morton B, Dudgeon D (eds) Proc 2nd Int Workshop Malacofauna of Hong Kong and Southern China, Hong Kong, 1983. Hong Kong University Press, Hong Kong, p 465-471

Jones TO, Iwama GK (1991) Polyculture of the pacific oyster, Crassostrea gigas (Thunberg), with chinook salmon, Oncorhynchus tshawytscha. Aquaculture 92:313-322

Kamermans P (1994) Similarity in food source and timing of feeding in deposit- and suspension-feeding bivalves. Mar Ecol Prog Ser 104:63-75

Karakassis I, Tsapakis M, Hatziyanni E, Papadopoulou KN, Plaiti W (2000) Impact of cage farming of fish on the seabed in three Mediterranean coastal areas. ICES J Mar Sci 57:1462-1471

Kharlamenko VI, Kiyashko SI, Imbs AB, Vyshkvartzev DI (2001) Identification of food sources of invertebrates from the seagrass Zostera marina community using carbon and sulfur stable isotope ratio and fatty acid analyses. Mar Ecol Prog Ser 220:103-117

Kreeger DA, Newell RIE (2001) Seasonal utilization of different seston carbon sources by the ribbed mussel, Geukensia demissa (Dillwyn) in a mid-Atlantic salt marsh. J Exp Mar Biol Ecol 260:71-91

Langdon CJ, Newell RIE (1990) Utilization of detritus and bacteria as food sources by two bivalve suspension-feed- ers, the oyster Crassostrea virginica and the mussel Geukensia demissa. Mar Ecol Prog Ser 58:199-310

Larsson AM (1985) Blue mussel sea farming-effects on water quality. Vatten 41: 218-224

Lehane C, Davenport J (2002) Ingestion of mesozooplankton by three species of bivalves: Mytilus edulis, Cerastoderma edule and Aequipecten opercularis. J Mar Biol Assoc UK 82:615-619

Leung KMY, Chu JCW, Wu RSS (1999) Nitrogen budgets for the areolated grouper, Epinephelus areolatus, cultured under laboratory conditions and in open-sea cages. Mar Ecol Prog Ser 186:271-281

Mazzola A, Sará G (2001) The effects of fish farming organic waste on food availability for bivalve mollusks (Gaera Gulf, Central Tyrrhenian, MED): stable carbon isotopic analysis. Aquaculture 192:361-379

McClelland JW, Valiela I (1998) Changes in food web structure under the influence of increased anthropogenic nitrogen inputs to estuaries. Mar Ecol Prog Ser 168:259-271

Nichols PD, Klumpp DW, Johns RB (1985) Lipid components of the epiphyte material, suspended particulate matter and cultured bacteria from a seagrass Posidonia australis community as indicators of carbon source. Comp Biochem Phys B 80:315-325

Owens NJP (1987) Natural variations in ${ }^{15} \mathrm{~N}$ in the marine environment. Adv Mar Biol 24:389-451

Page HM, Hubbard DM (1987) Temporal and spatial patterns of growth in mussels Mytilus edulis on an offshore platform: relationships to water temperature and food availability. J Exp Mar Biol Ecol 111:159-179

Page HM, Lastra (2003) Diet of intertidal bivalves in the Ria de Arosa (NW Spain): evidence from stable C and N isotope analysis. Mar Biol 143:519-532

Pearson TH, Black KD (2001) Chapter 1. The environmental impacts of marine fish cage culture. In: Black KD (ed) Environmental impacts of aquaculture. Sheffield Academic Press, Sheffield, p 1-31

Peterson BJ, Fry B (1987) Stable isotopes in ecosystem studies. Annu Rev Ecol Syst 18:293-320

Phillips DL (2001) Mixing models in analyses of diet using multiple stable isotopes: a critique. Oecologia 127:166-170

Phillips DL, Koch PL (2002) Incorporating concentration dependence in stable isotope mixing models. Oecologia 130:114-125

Sargent JR, Parkes RJ, Mueller-Harvey I, Henderson RJ (1987) Lipid biomarkers in marine ecology. In: Sleigh MA (ed) Microbes in the sea. Ellis Horwood, Chichester, p 119-138

Shpigel M, Gasith A, Kimmel E (1997) A biomechanical filter for treating fish-pond effluents. Aquaculture 152:103-117

Siddall SE (1980) A clarification of the genus Perna (Mytilidae). Bull Mar Sci 30:858-870

SPSS (1999a) SPSS base 9.0 user's guide. SPSS, Chicago

SPSS (1999b) SPSS base 9.0 application guide. SPSS, Chicago

Stirling HP, Okumus I (1995) Growth and production of mussels (Mytilus edulis L.) suspended at salmon cages and shellfish farms in two Scottish sea lochs. Aquaculture 134: $193-210$

Strickland JDH, Parsons TR (1972) A practical handbook of seawater analysis. Canadian Government Publishing Center, Ottawa

Taylor EB, Jamieson G, Carefoot TH (1992) Mussel culture in British Columbia: the influence of salmon farms on growth of Mytilus edulis. Aquaculture 108:51-66

Vizzini S, Sará G, Michener RH, Mazzola A (2002) The role and contribution of the seagrass Posidonia oceanica (L.) Delile organic matter for secondary consumers as revealed 
by carbon and nitrogen stable isotope analysis. Acta Oecologica 23:277-285

Widdows J, Fieth P, Worrall CM (1979) Relationship between seston, available food and feed activity on the common blue mussel Mytilus edulis. Mar Biol 50:195-207

Wong WH, Cheung SG (1999) Feeding behavior of the green mussel, Perna viridis (L.): responses to variation in seston quantity and quality. J Exp Mar Biol Ecol 236: 191-207

Wong WH, Cheung SG (2001) Feeding rates and scope for growth of Green mussels, Perna viridis (L.) and their relationship with food availability in Kat O, Hong Kong. Aquaculture 193:123-137

Wong WH, Cheung SG (2003) Site-related differences in the feeding physiology of the green mussel Perna viridis: a reciprocal transplantation experiment. Mar Ecol Prog Ser 258:147-159

Wong WH, Levinton JS (2003) Assimilation of micro- and mesozooplankton by mussels: a demonstration of the food web link between zooplankton and benthic suspension feeders. Limnol Oceanogr 48:308-312

Wong WH, Levinton JS (2004) Culture of the blue mussel

Editorial responsibility: John Lawrence (Contributing

Editor), Tampa, Florida, USA
Mytilus edulis fed both phytoplankton and zooplankton: a microcosm experiment. Aquac Res 35:965-969

Wu RSS, Lam KS, Mackay DW, Lau TC, Yam V (1994) Impact of marine fish farming on water quality and bottom sediment: a case study in the sub-tropical environment. Mar Environ Res 38:115-145

Yamamuro M (1999) Importance of epiphytic cyanobacteria as food sources for heterotrophs in a tropical seagrass bed. Coral Reefs 18:263-271

Ye L, Ritz DA, Fenton GE, Lewis ME (1991) Tracing the influence on sediments of organic waste from a salmonid farm using stable isotope analysis. J Exp Mar Biol Ecol 145: 161-174

Yokoyama H, Ishihi Y (2003) Feeding of the bivalve Theora lubrica on benthic microalgae: isotopic evidence. Mar Ecol Prog Ser 255:303-309

Yokoyama H, Higano J, Adachi K, Ishihi Y, Yamada Y, Pichitkul P (2002) Evaluation of shrimp polyculture system in Thailand based on stable carbon and nitrogen isotope ratios. Fish Sci 68:745-750

Zar JH (1999) Biostatiscal analysis, 4th edn. Prentice-Hall, Upper Saddle River, NJ

Submitted: April 1, 2005; Accepted: December 9, 2005

Proofs received from author(s): June 23, 2006 